\title{
The Intellectual Rights Protection Strategy for Leading Innovative Export Products: A Case of Up-Cycle Rustic Wood
}

\author{
Moh. Rusnoto Susanto ${ }^{1}$, Siti Mariah ${ }^{2}$, Kusuma Chandra Kirana ${ }^{3}$, \\ Shafa Selinamorita ${ }^{4}$, Anselmus Sudirman ${ }^{5}$ \\ \{rusnoto@ustjogja.ac.id\}
}

${ }^{1}$ Department of Science Education, UST Yogyakarta, Indonesia,

${ }^{2}$ Family Welfare Vocational Education Universitas Sarjanawiyata Tamansiswa Yogyakarta, Indonesia, ${ }^{3}$ Manajemen Program, Universitas Sarjanawiyata Tamansiswa Yogyakarta, Indonesia, ${ }^{4}$ International Communication Studies Program, Faculty of Social and Political Science (FISIPOL), Universitas Muhammadiyah Yogyakarta, Indonesia, ${ }^{5}$ English Education Department, Universitas

Sarjanawiyata Tamansiswa Yogyakarta, Indonesia

\begin{abstract}
Government support for creative industries prioritizes local material processing and local creative human resources with high competitiveness. Rustic Wood products are profane products that reinforce the aesthetic elements of today's prospective residential interior. This is in line with the 2015-2019 LIPI RENSTRA, creating scientific inventions that can encourage innovation to increase the nation's economic competitiveness (LIPI Strategic Plan, 2015). Government support for the creative industry has prioritized Upcycle, local human resources with global competitiveness. Rustic Wood products are profane products. They reinforce the aesthetic elements of today's prospective residential interior characters in line with modern residential concepts. The objectives of this research are (1) increasing the global competitiveness of Rustic Wood Upcycled products with innovative designs, (2) strengthening the exploration pattern of forms and aesthetics through strengthening design innovation with due diligence of IPR products, (3) Increasing legal protection of prototype Intellectual Property Rights (HKI) for superior export products of rustic wood. Qualitative research with a phenomenological approach focuses on the empirical experience of industrial players in the development of rustic wood export products based on strengthening innovative designs, through the following stages: (1) Exploration of field data on partner industries, (2) ensuring data sources (participants), (3) compiling instruments, (4) data analysis and representation, (5) trust criteria, (6) reflectivity of research findings. The research results show (1) the priority to increase the competitiveness of Rustic Wood Upcycled products with innovative designs, (2) explanation of strategies for strengthening exploration patterns of forms and aesthetics through design innovation as the feasibility of IPR products, (3) describing the process of enhancing intellectual rights protection (IPR) attached to prototypes or superior export products of rustic wood.
\end{abstract}

Keywords: Intellectual Property Rights (HKI), UpCycle, Rustic Wood, Export Products 


\section{Introduction}

In the 2017-2045 RIRN, the Ministry of Research, Technology, and Higher Education focuses on research on Social Humanities, Arts, and Culture. Education through Economic and Human Resources Studies specifically on research topics on Entrepreneurship, cooperatives, and MSMEs focuses on the design of strengthening national local cultural arts as the backbone of tourism. This is in line with the 2015-2019 LIPI RENSTRA. It creates scientific inventions that can encourage innovation to increase the nation's economic competitiveness.

The Industrial Revolution 4.0 Era requires the synergy of government, society, researchers, and creative industry business practitioners to increase creative, innovative, and highly competitive human resources. Explicitly at the 2017-2045 Ministry of Research, Technology and Higher Education's RIRN, the focus of research on Social Humanities-Arts and Culture-Education through Economic and Human Resources Studies specifically on research topics on Entrepreneurship, cooperatives, and MSMEs is oriented towards the design of strengthening national, local, and cultural arts as the backbone of tourism. (RIRN Kemenristek Dikti, 2017).

This is in line with the 2015-2019 LIPI RENSTRA, creating scientific inventions that can encourage innovation to increase the nation's economic competitiveness. (LIPI Strategic Plan, 2015). Government support for the creative industry has prioritized Upcycle, local human resources with global competitiveness. Rustic Wood products reinforce the aesthetic elements of today's perspective and interior characters concerning modern residential concepts.

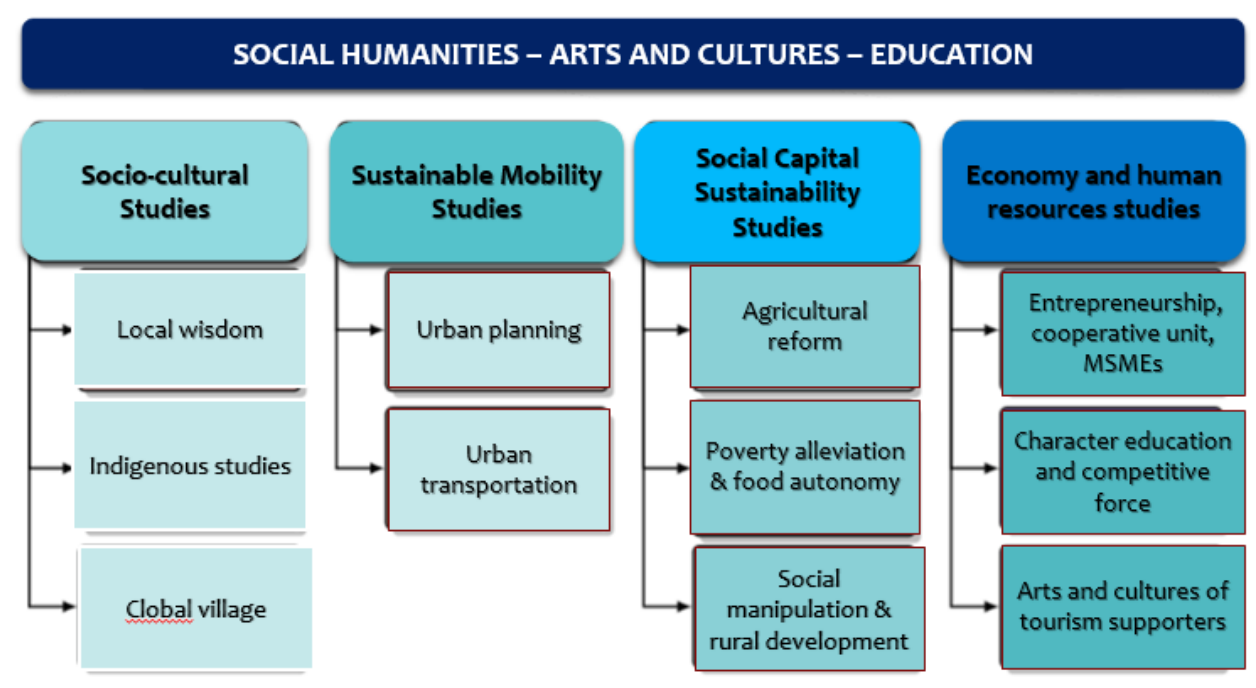

Figure 1. Themes and Topics for Social Humanities, Arts, and Culture Research

(Source: RIRN Kemenristek Dikti, 2017:84)

Creative Industry since the 2000s as an influential economic source introduced by John Howkins (2001) that economic growth depends on new ideas. Presidential Instruction N0. 6 of 2009 concerning Creative Economy Development in Indonesia established the Creative Economy Agency (Bekraf). Hidayat and Asmara (2019) state that In this term, the perspective of the regional innovation system is also important to understand what is the creative industry 
expected by the Government of Indonesia. Innovation and the creative economy are two terms, which are unseparated from each other. The creative industry is a priority to support export foreign exchange based on the quality of human resources and superior products. Zahry (2017: 1) states that creative industries have been identified as a new engine of growth in that human capital, technology, tolerance, education, amenities and infrastructure, and governance are the factors considered in locating creative industries in a city.

The UPCYCLE-based creative industry continues to innovate with IPR protection through the synergy between the Directorate General of IPR, academics, and creative industry players who intensively cooperate. Thus, competitions seize great opportunities in the global market (Susanto, 2015).

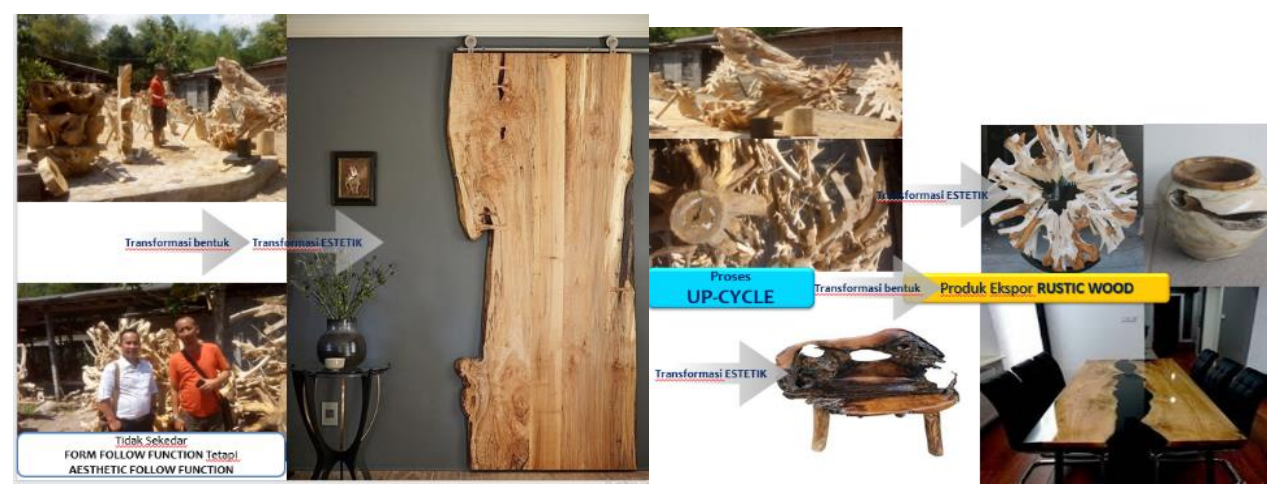

Figure 2. Up-Cycle Based Rustic Wood Products

The Creative Economy is known globally (Howkins, 2001). Howkins realized the emergence of a new economic wave based on creativity in 1997 after the United States produced Intellectual Property Rights (IPR) products. Howkins briefly defines the Creative Economy, namely: "The creation of value as a result of the idea". The latest Creative Economy Study conducted by the United Nations Conference on Trade and Development (UNCTAD) in 2010 "An evolving concept based on creative assets potentially generating economic growth and development." Export Product Development in the Creative Industry is a Blueprint for the National Creative Economy Development 2009-2015 (Deperindag, 2008).

Creative Economy is defined as follows: "The new era of the economy after the agricultural economy, industrial economy, and information economy, which intensifies information and creativity by relying on ideas. and knowledge of human resources as the main production factor in their economic activities. The definition of Creative Industries according to DCMS Creative Industries Task Force (1998): “Creative Industries as those industries which have their origin in individual creativity, skill \& talent, and which have a potential for wealth and job creation through the generation and exploitation of intellectual property and content. (Ministry of Industry and Trade, 2008).

Research problems are based on field facts, namely (1) Weak competitiveness of Rustic Wood Upcycled products. (2) Lack of exploration of forms and aesthetics in rustic wood products. (3) The need to improve the qualifications of superior creative human resources. (4) Weak IPR protection of designs and products. (5) The importance of testing the rustic wood material with export standards and testing the design model and the feasibility of production has received legal protection over intellectual rights. The objectives of this research are (1) increasing the global competitiveness of Rustic Wood Upcycled products with innovative 
designs, (2) strengthening the exploration pattern of forms and aesthetics through strengthening design innovation with due diligence of IPR products, (3) increasing legal protection of prototype Intellectual Property Rights (HKI) for superior export products of rustic wood.

\section{Research Methods}

This type of research is qualitative research with a phenomenological approach. The reason for choosing this approach is because of the problems studied, the empirical experience of creative rustic wood industry players in transforming their creative ideas through the processing of teak wood fossil waste which can be explored as a representation of the social context and other cultural contexts. Potton (2002: 106) has a recent dimension that distinguishes the phenomenological approach, namely the assumption that there is a firm attitude to share experiences. These principles are for understanding through general phenomena and have a phenomenological focus (deriving from the experience of some phenomena).

According to Husserl, three steps are required to reduce data, namely (1) phenomenological reduction for all concepts or theories regarding the symptoms or behavior that we investigate, (2) eidetic reduction is essential for the symptom in question, even though we see it physically connected. (3) Transcendental reduction: in transcendental reduction, we act very radically (as in phenomenological reduction), as well as observed symptoms (as in eidetic reduction). Sources of research data (participants) in phenomenological research are following Creswell's instructions (2007) in determining the minimum number of participants, but the authors determine the number of participants above is minimal.

In the study, 7 participants were involved consisting of 5 male participants and 3 female participants consisting of the creative team, the production team, the marketing team, and the management team. All primary data were obtained through an interview process with the Secretary, Cashier, Export Manager, Production Planning and Inventory Control, PT Roma Export. As well as giving questionnaires to 12 staff, including the Secretary, Cashier, Export Manager, Export Assistant, PPIC, Warehouse Admin, Purchasing, Terazzo Leader, Buddhist Leader, Furniture Leader, Public Work Leader, Household. (Fitriyani, 2015).

\section{Results and Discussion}

In recent years the government has been promoting what is called creative arts. The creative arts industry continues to hope that creative arts will provide new inspiration in global competition. Because, in the global era, when creativity makes new products economically acceptable to the consumer community, the competitiveness is getting stronger. Thus, a macro manner can form a creative economy. A form of effort needs to find a meeting point for sustaining community, economic development, and creativity. A sustainable and highly competitive economic climate was also formed, supported by reserves of renewable and efficient resources.

This is a fragment of Mari Elka Pangestu's lecture, "Development of Indonesia's Creative Economy 2009-2025", a paper presented at a National Seminar entitled "Triple Helix Accentuation in the Realization of Creative Economy" in the context of the 24th Anniversary 
of ISI Yogyakarta on August 9, 2009. This increasing optimism considers that the people have high creativity with sufficient economic resilience. They do not only survive in the national economic crisis and the global economy but can rise. This is of course very important because it can be an asset to prepare the Indonesian people for the 2015 ASEAN Economic Community (AEC). A strategic ASEAN community opens economic perspectives and dialogues between nations in various sectors in ASEAN countries (Susanto, 2015: 555).

The handicraft industry in Yogyakarta stimulates the growth of the economy of the surrounding community. People in Bantul Yogyakarta design and produce export products. They take a position as a local creative industry which has its characteristic strength as a socio-cultural capital. The weak tradition of conducting design innovation is now being challenged by considering several academics, researchers, and business actors who carry out research, development, and mastery of appropriate technology from the perspective of creating value for innovation. High technology mastery innovation develops in the practice of managing and developing small and medium industries such as the development of craft industry centers to produce new values.

The creative process of creating or creating something with sensory abilities possessed both real and imaginative in which it plays fantasy or imagination freely and boldly, without needing to be limited by subjective concerns. (Retantoko, 2016). The creative process means the freedom to develop ideas and ideas freely. How much risk will be taken, depending on how big the quality of the creativity is. Someone who dares to take risks, of course, will be able to develop their business forward, now and in the future (Kompasiana, 15 May 2011). Rustic Wood Teak Wood Fossil Waste is widely known for its quality when furniture or the like is referred to as quality teak wood that craftsmen and the handicraft industry attract as the main raw material for rustic wood which is currently popular. Prabowo (2002: 10) explains that each type of wood has different characteristics. The different characteristics of wood are related to the anatomical characteristics of wood, namely physical, mechanical, and chemical properties. Only a few types of wood can be created as carvings, reliefs, sculptures, furniture, or house buildings (Soepratmo, 2004).

The position of teak root rustic wood waste used as the main raw material is a smart way to process waste that will be wasted and has no economic value, the same position as other waste or waste including paper waste. The paper is currently in the hands of the creator and has been up-cycled in such a way as usual batik artists have been exploring paper waste as a printing tool to replace copper. Papers are selected from the types of packaging papers used in the secondary packaging sector of supermarkets and waste can be reduced (Dixon-Hardy \& Curran, 2009).

Starting from various experiments ranging from plastic, wood, and others. Batik paper stamp material is the most effective success rate. The use of waste paper as a solution to problems arises from the emergence of waste paper, which is not used as part of the improvement due to environmental disturbances due to industrial process waste (Ferraro et al. 2020). All wood waste materials are used as the main raw material for rustic wood produced by $\mathrm{CV}$. Amartha Indotama has gone through a natural drying process and a preservation process considered to adjust to various weather and climates. Microstructural examination reveals the directional folding of parenchyma cells resulting from the compression. It reduces intercellular micro-voids during the drying process. A non-directional collapse of parenchyma cells results from a capillary force (Rittiphet, 2021).

A series of wood selection processes with various treatments produce quality wood with different class specifications. As is generally known in the wood processing industry. Based on the Indonesian standard, in which class I indicates very resistant wood and class V 
indicates very poorly resistant wood, untreated wood was class IV, but all furfurylated wood specimens were rated as class I. (Hadi, 2021).

The types of wood favored for the manufacture of carvings, reliefs, and sculptures are Sonokeling wood, Sonokembang wood, teak wood, mahogany wood, Jelutung wood, ebony, sandalwood, ironwood, lasi wood (Soepratmo, 2004). Utilization of waste can provide benefits in terms of forestry, the wood industry in optimizing wood use and saving monthly family expenses, and increasing soil fertility (Malik, 2013). For example, the processing of palm wood is confirmed by Rittiphet (2021) that to prevent defects caused by drying collapse, transverse pre-mechanical compression with lateral restraint of green oil palm wood (OPW) before kiln-drying was performed.

Strengthening Upcycle-based Design Innovation, The creative industry has been identified as a new engine of growth driven by the availability of human resources, technology, tolerance, education, infrastructure facilities, and governance. The government has shown its siding with a more progressive and classy creative economy in the global market. Rustic Wood is a worn object and aesthetic element that reinforces the character of today's residential interiors.

For now, the main priority is to develop innovative products based on Up-Cycle. It focuses on innovation in the design of superior export products. The business pioneering activities and the dynamics of Up-Cycle-based rustic wood exports provide prospective opportunities for the development of creative industry MSMEs, increasing productivity, and product quality. Governments, researchers, and community service providers take a strategic role in intervening in the program. Various programs aim to strengthen the quality of human resources.

The quality achievement and the innovative design solely rest on creativity, innovation in aesthetic forms, and profane functions. E-Commerce Based Marketing Strategy, building an integrated online financial management, marketing, and tax reporting system. E-Commerce needs to be strengthened by providing PIXEL links from WEB to business IG with Up-toDate interconnections. Innovative designs also need the support of a good and effective marketing system to support new ideas or findings of new processes or effective methods that are taken to produce fresh and up-to-date new creative ideas that require good imagination and visualization power. (Retantoko, 2016). Practical (profane) needs-oriented creators market their superior export products through a marketplace that is supported by the dearth of the ECommerce system. Many applications and patterns of ongoing training assistance also help Partners in strengthening the marketing system.

Hilmiana, Imas Soemaryani, Joeliaty (2020) emphasize the role of government in the quadruple helix of $60 \%$ in 2016 , decreasing to $10 \%$ in 2019 . The decreasing government role is also accompanied by the increasing role of creative entrepreneurs each year (55 percent in 2019). It shows that the development of the creative economy is becoming more independent every year. He emphasized the increasing role of creative entrepreneurs every year ( 55 percent in 2019). This shows that the development of the creative economy is increasingly independent every year.

At the intervention stage, research activities are desirable to build a teamwork climate with communication skills, project management, the ability to perform and a personal attitude are important in organizing an event. The same thing was emphasized by Siti Hafizah Binti Daud, Mashita Binti, M.Zin, Myzatul Zeiha Binti Yusof (2019) in the article 'Cooperative Learning In Event Management: A Case Study Of Edventure Of Beauty \& The Beast' International Journal Creative Industry (IJCREI), Volume: 1 Issue: 1 (March 2019) that, for soft skills, the study found that communication, teamwork, creative thinking, time 
management, event management, and management are the skills needed to be improved in the future. Various studies describe the important roles of soft skills and hard skills. They strengthen e-commerce business of communication strategy skills, HR synergy in teamwork, creative thinking competencies, time management skills, financial management, and studio and workshop management is the most important capital for SMEs that need to continue. be improved in the future.

If we take a detailed look at upcycle-based rustic wood products, the value and visual presentation, and application technology of their creation techniques have shifted. Craftsmen design innovations and the global markets demand designers' creativity and the need for innovation in aesthetic forms. Not only the value of design innovation and appearance, but this value of a product is determined by the product design, the quality of the materials, the difficulty level of workmanship, and the inherent function value of the product itself.

New values emerge from the creative awareness of convergence of previous technologies to produce new ideas or inventions of new processes or effective methods that are taken to produce fresh and up-to-date new creative ideas that require good imagination and visualization power. Creators are creatively oriented to adjust to absorption and practical needs (profane) of contemporary societies that appear in the centers of creative industries.

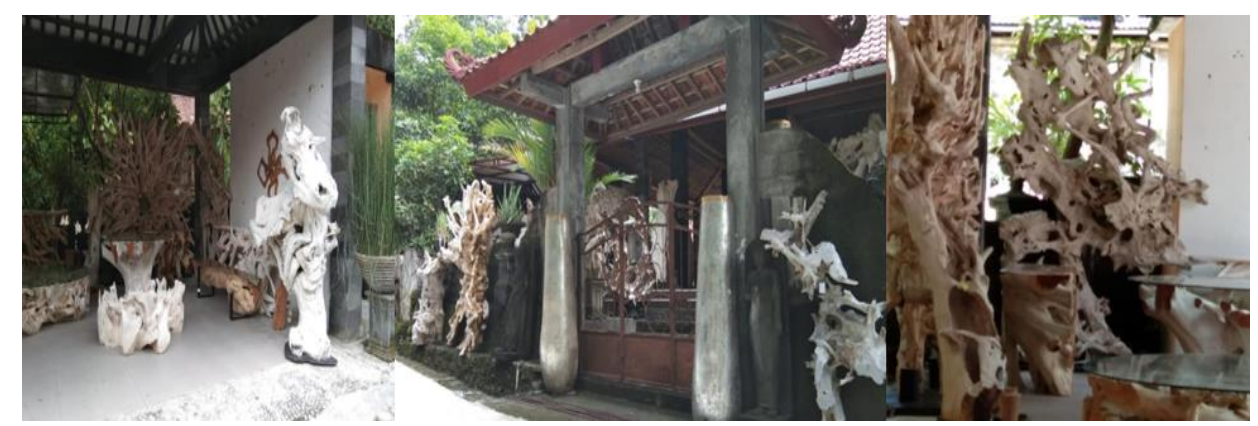

Figure 3. Rustic Wood Workshop

The current economic movement is strongly influenced by globalization, one of the products of globalization is Intellectual Property Rights (IPR), which is the capitalization of one's intellectual (creative capital) which can protect creative and innovative ideas and limit others to exercise their rights. However, in reality, people involved in the creative industry, especially in Yogyakarta are unaware of protecting their intellectual rights. The creative ideas explore rustic wood products as interior elements patented or registered for design copyright at the Directorate General of Copyright.

The objective is to obtain legal copyright protection and protect business interests so that products, patents, brands, and design copyrights are not explored or exploited by other parties. They have a value related to the specificity of their products in front of the global market. This does not violate the public's perception of the complexity and the IPR processing process when registering technology products with potential patents. The expansive view of subject matter protectable via intellectual property law has based the clear delineation between patent, copyright, and trademark law. (Beckerman, 2011).

Breyer in Andrew Beckerman (2011) states that this can work to the detrimental public if the intellectual property, for example, involves a life-saving drug or treatment. The goal of any legal protection is to find the optimization such that enough protection is provided by the law to maximize the investment of time, energy, and capital in creative endeavors while 
minimizing any restriction on the public's freedom to use products resulting from such creativity.

Copyright Product designs and simple patents are important for the protection of intellectual rights, legal protection rights, economic rights, and industrial product business rights (Susanto, 2015). The growth of this creative industry, in general, shows a significant development. When intellectual rights are protected, the creative industry is encouraging the formation of stakeholder trust, which impacts the quality of life and welfare and business progress that is increasingly competitive globally.

As emphasized by Robert L. Ostergard (2020), the enforcement component, however, becomes even more critical given the Trade-Related Aspects of Intellectual Property Rights (TRIPS) agreement under the World Trade Organization. Thus, science and technology are related to the ability of creative industry players. SMEs and MSMEs encourage people to acquire IPR certification, Design Copyright, Art Copyright, and Simple Patent filing. They can strengthen the rustic woodcraft industry. An upcycling is highly competitive and has an impact on the expansion of the global market network. Efforts are made to improve product quality, business governance, IPR regulation, and marketing strategies in small and medium industries. They can contribute to business progressivity in increasing the quantity, quality, and competitiveness of products to reach the global market.

\section{Conclusion}

The creative industry can increase creative ideas in the rustic woodcraft industry center, which is processed by upcycling in Guwosari Bantul has a high contribution to the creative industry business movement. Social and cultural capitals can strengthen the regional economy, the creative industry sector, and the tourism movement. The creative industry has a creative capital producer orientation to stimulate local creative industries, such as the rustic woodcraft industry, which is processed on an upcycling to have high competitiveness in the global market. MSMEs are creative, innovative, resilient, competitive, and have intellectual rights protection so that their innovative products have high bargaining value in the open space of the global market. Strategies to strengthen exploration patterns of shapes and aesthetics through design innovation as the feasibility of IPR products. The weak competitiveness of Rustic Wood Upcycled products in the global market requires the support of all stakeholders. The authorities maintain intellectual property rights, research, and development. Using appropriate technology, the craftsmen create value innovations carried out synergistically.

An innovative strategy for enhancing the protection of intellectual rights (IPR) inherent in prototypes or superior export products of rustic wood. CV. Amartha Indotama as a rustic wood industry player who is oriented towards decorative and functional objects that complement the interior is aware that there is still a need to continue to carry out various studies, exploration of forms, techniques, and aesthetics on highly competitive rustic wood products. The need to increase the qualifications of superior creative human resources to produce unique innovative products that have the potentials to obtain IPR protection both in design products and in prototypes that are ready to be marketed. Thus, the value of rustic wood products is increasingly high in value both aesthetically and in economic value. It is essential to test the rustic wood material with export standards and testing the design model as well as the feasibility of production that has obtained legal protection for intellectual rights. Through a process and support that encourages, motivates, and builds awareness for 
craftsmen, conception, and designers about the importance of registering their design of innovative products in the IPR category. Innovative design products are related to the mastery of high technology. They are gradually changing their orientations to innovations in the discourse and practice of small and medium industries.

\section{References}

[1] Beckerman, Andrew -Rodau, 2011. The Problem With Intellectual Property Rights: Subject Matter Expansion, Yale Journal of Law and Technology, Volume 13 Issue 1, 13Yale J.L. \& Tech(2011).

[2] Darron W. Dixon-Hardy \& Beverley A. Curran. 2009. Types of packaging waste from secondary sources (supermarkets)-The situation in the UK, Waste Management 29 (2009) 1198-1207

[3] Deperindag. 2008. "Pengembangan Ekonomi Kreatif Nasional 2009-2015." Departemen Perindustrian dan Perdagangan RI, Jakarta, 2008.

[4] Dikti, 2017. Rencana Induk Riset Nasional (RIRN) Tahun 2017-2045. Jakarta

[5] Creswell, J. W. 2007.Qualitative Inquiry And Design Research: Choose Between Five Approach. Thousand Oaks, CA: Sage Publications, 2007.

[6] Ferraro, Alessandra, Marco Pirozzi, Enrico Annacondia, and Luciano Di Donato. 2020. "Powder Bed Fusion/Sintering Machines: Safety at Workplaces.” Procedia Manufacturing 42 (2019): 370 74. https://doi.org/10.1016/j.promfg.2020.02.061

[7] Fitriyani. 2015. "Analisa Strategi Pemasaran Ekspor Cv Amartha Indotama Dalam Memasuki Pasar Global,” J. Bisnis, vol. 6 No 2, no. UNY, Yogyakarta, p. 146, 2015.

[8] Hadi, Yusuf Sudo, Desy Mulyosari, Elis Nina Herliyana, Gustan Pari, Wa Ode Muliastuty Arsyad, Imam Busyra Abdillah, Philippe Gérardin. 2021. Furfurylation of wood from fast-growing tropical species to enhance their resistance to subterranean termite, European Journal of Wood and Wood Products (2021), Published 09 March 2021. https://doi.org/10.1007/s00107-021-01676-4

[9] Hafizah, Siti Binti Daud, Mashita Binti M. Zin , Myzatul Zeiha Binti Yusof.2019. 'Cooperative Learning In Event Management: A Case Study Of Edventure Of Beauty \& The Beast' International Journal Creative Industry (IJCREI), Volume: 1 Issue: 1 (March 2019), p. 1

[10] Hidayat and Asmara, "Creative Industry In Supporting Economy Growth In Indonesia: Perspective Of Regional Innovation System,” IOP Conf. Ser. Earth Environ. Sci., vol. 379,

[11] Hilmiana, Imas Soemaryani, Joeliaty. 2020. 'Strategic Partnership Model On Creative Economy Development In Indonesia Based On Local Arts And Culture In Bandung Regency' pada International Journal Creative Industry, (IJCREI), Volume: 2 Issues: 3 (March 2020), p.1

[12] J. Howkins, J. 2001. The Creative Economy: How People Make Money from Ideas.

[13] Lembaga Ilmu Pengetahuan Indonesia. (LIPI). 2015. Rencana Strategis (RENSTRA) LIPI 20152019. Jakarta.

[14] Malik, U. 2013. "Alternatif Pemanfaatan Limbah Industri Pengolahan Kayu Sebagai Arang Briket," J. APTEK, vol. 5 No 1, no. Jurusan Fisika Fakultas MIPA Universitas Riau.

[15] Pangestu, Mari Elka "Pengembangan Ekonomi Kreatif Indonesia 2009-2025", makalah disampaikan pada Seminar Nasional bertema "Aksentuasi Triple Helix dalam Realisasi Ekonomi Kreatif” dalam rangka Dies Natalis ISI Yogyakarta ke 24 pada 9 Agustus 2009

[16] Prabowo, S. 2002. Kerajinan Kayu. Surabaya: Unesa University Press, 2002.

[17] Potton, M.Q. 2002. "Qualitative Research and Evaluation Methods," 3 Edition., Thousand Oaks, London, New Delhi: Sage Publications.

[18] Retantoko, Cokro. 2016."Pemanfaatan Limbah Kayu Jati Dalam Pembuatan Karya Seni Kriya Kayu Berbentuk Naga Eropa,” Jurnal Pendidikan Seni Rupa, Volume 04 Nomor 03 Tahun 2016, 374-380 374, Pendidikan Seni Rupa, Fakultas Bahasa dan Seni, UNESA Surabaya, pp. 374-380,

[19] Rittiphet, Choosak. Kamolwun Dumyang \& Nirundorn Matan. 2021. Effect Of Pre-Mechanical Compression On Free Water Removal, Drying Collapses And Associated Internal Voids Of Oil 
Palm Wood, European Journal of Wood and Wood Products (2021), published 06 March 2021. https://doi.org/10.1007/s00107-021-01674-6

[20] Robert L. Ostergard, Jr. 2020. The Measurement of Intellectual Property Rights Protection, Journal of International Business Studies, February 2000, DOI: 10.1057/palgrave.jibs.8490911

[21] Susanto, Moh. Rusnoto. 2015. "Peran Strategis Sertifikasi HKI Pada Produk Industri Kreatif Dalam Menyongsong MEA 2015," Proseding Seminar Nasional 'Peluang, Tantangan, dan Strategi Menyongsong MEA 2015. LP2M UST Yogyakarta, Yogyakarta, p. 1.

[22] Susanto, Rusnoto. 2015. Membangun Kesadaran Hak Kekayaan Intelektual (HKI) Inovasi Desain Produk Kerajinan Rustic Wood yang diolah Secara Upcycle Dalam Menghadapi MEA 2015. Seminar Nasional Universitas PGRI Yogyakarta 2015, Yogyakarta: 26 Desember 2015. ISBN 978 602-73690-3-0, p. 554-558

[23] Susilo, Je, Bembeng. 2011. Proses Kreatif !, Kompasiana, 15 Mei 2011, https://www.kompasiana.com/bambangjes/5500c805a33311ac0a510a25/proses-kreatif?page=all

[24] Soepratno. 2004. Mengenal Budaya Bangsa Indonesia: Ornamen Ukir Kayu Tradisional Jawa 2. Semarang: Effhar \& Dahara Prize.

[25] Zahry, SM. 2017. "Arts, Antiques, and Craft Businesses Locational Choice: The Case of George Town, Penang,” Int. J. Cult. Creat. Ind., vol. 4, no. 2, p. 1 